\title{
Erratum to: Changes in Vesicular Transport of a Model Fluorescent Protein in the Renal Proximal Tubular Epithelium of the Frog Rana temporaria after Lysozime Loading
}

\author{
N. P. Prutskova ${ }^{a *}$ and E. V. Seliverstova $a$ \\ a Sechenov Institute of Evolutionary Physiology and Biochemistry, Russian Academy of Sciences, \\ St. Petersburg, Russia \\ *e-mail: natprut@yandex.ru \\ Received June 14, 2018 \\ Revised September 26, 2018 \\ Accepted October 2, 2018
}

DOI: $10.1134 / \mathrm{S} 0022093019030141$

On page 158. In the title of the article Lysozime should read Lysozyme.

The original article can be found online at https://doi.org/10.1134/S0022093019020108 